\title{
ANALISIS KINERJA CHILLER DI GEDUNG SENAYAN CITY
}

\author{
Maya Firanti Putri ${ }^{1}$, Massus Subekti ${ }^{2}$, Aris Sunawar ${ }^{3}$,
${ }^{1}$,.3. Pendidikan Teknik Elektro, Fakultas Teknik, Universitas Negeri Jakarta \\ 1Email : maya.elektro@gmail.com
}

\begin{abstract}
.
Research conducted in the building Senayan City in June 2016 using qualitative research methods. Standards are used as a benchmark the performance of each chiller uses ISO 6390 in 2011 on Energy Conservation Air system administration Building. These aspects are analyzed to determine the performance of the chiller is the temperature of chilled water, flow chilled water and compressor power. As for the influence of the three aspects is the temperature of the outside environment. By calculating the cooling capacity, the highest Coefficient of Permonace (COP) value can be determined each chiller. Chiller performance analysis results obtained COP value of the highest attainable number 1 at 7.31 chiller, chiller number 2 at 8.03 and chiller number 3 6:27. These values meet the mi nimum value of COP according to ISO standards. Lowest chiller COP value number 1 by 5.08, number 2 for 5.12 chiller and chiller number 3 at 4.22 . Third party chiller COP minimum value does not meet the minimum standards of the COP. Chiller number 3 has the lowest minimum number COP and far below the minimum stadar.Judging from the value of cooling capacity and COP, chiller performance is not good enough is the number 3. And the chiller that has good enough performance is number 1 and 2
\end{abstract}

Keywords :Chiller, Air System Administration, And Coefficient of Permonace (COP)

\begin{abstract}
Abstrak
Penelitian ini bertujuan untuk menghasilkan data analisis kinerja chiller di gedung Senayan City. Penelitian yang dilakukan di gedung Senayan City pada bulan Juni 2016 ini menggunakan metode penelitian kualitatif. Standar yang digunakan sebagai patokan kinerja masing-masing chiller menggunakan SNI 6390 tahun 2011 tentang Konservasi Energi Sistem Tata Udara Bangunan Gedung. Aspek-aspek yang dianalisis untuk mengetahui kinerja chiller adalah temperatur chilled water, flow chilled water dan power kompresor. Adapun yang mempengaruhi ketiga aspek tersebut adalah temperatur lingkungan luar. Dengan menghitung kapasitas pendinginan, dapat ditentukan nilai Coefficient of Permonace (COP) tertinggi masing-masing chiller. Hasil analisis kinerja chiller didapat Nilai COP tertinggi yang dapat dicapai chiller nomor 1 sebesar 7,31, chiller nomor 2 sebesar 8,03 dan chiller nomor 3 6.27. Ketiga nilai tersebut memenuhi nilai minimum standar COP menurut SNI. Nilai COP terendah chiller nomor 1 sebesar 5,08, chiller nomor 2 sebesar 5,12 dan chiller nomor 3 sebesar 4,22. Ketiga nilai minimum COP ketiga chiller ini tidak memenuhi standar minimum COP. Chiller nomor 3 mempunyai angka minimum COP paling rendah dan jauh dibawah stadar minimum. Dilihat dari kapasitas pendinginan dan nilai COP, chiller yang kinerja kurang baik adalah chiller nomor 3 . Dan chiller yang performanya cukup baik adalah chiller nomor 1 dan 2.
\end{abstract}

Kata Kunci: $\quad$ Chiler, Sistem Tata Udara, Sistem Referigerasi, Dan Konservasi Energi

\section{PENDAHULUAN}

Seiring perkembangan jaman dari waktu ke waktu pembangunan gedung-gedung bertingkat semakin berkembang pesat, oleh karena itu di daerah padat penduduk dan pembangunan serta sangat minimnya lahan hijau seperti di Jakarta ini sangat sulit membangun gedung-gedung beriklim tropis yang masih asri dengan udara yang sejuk. Akibatnya, udara di dalam ruangan justru lebih panas dan pengap. Oleh karena itu, solusi dari masalah ini adalah dengan menggunakan penyejuk ruangan (Air Conditioning/AC). Pada gedung-gedung bertingkat, sistem penyejuk ruangannya menggunakan AC sentral yang disebut Chiller. Hal ini dikarenakan melihat biaya operasional dan perawatan Chiller yang mudah dan murah.

Chiller beroperasi di siang hari sama seperti sistem AC pada umumnya. Peforma chiller tentu akan berbeda pada saat siang dan malam hari. Di Senayan City, terdapat empat unit chiller dengan tiga unit chiller berkapasitas 2000 TR(Ton Refrigeran) dan 
satu unit chiller berkapasitas 800 TR. Setiap harinya ada tiga unit yang beroperasi yakni dua buah chiller berkapasitas 2000 TR dan satu buah chiller berkapasitas 800 TR. Efisiensi energi saat ini telah menjadi bagian dari kebutuhan operasional sarana bangunan. Menurut Data Audit Energi Senayan City tahun 2013, Senayan City sendiri energi untuk sistem pendingin mengkonsumsi paling banyak energi sekitar 40\%. Maka dari itu perlu kinerja chiller yang efisien sehingga dapat memperbaiki pula efisiensi konsumsi energinya. Ketiga chiller yang beroperasi belum tentu memiliki kinerja yang sama, walaupun mempunyai kapasitas terpasang yang sama.

\section{METODE}

\section{Flowchart}

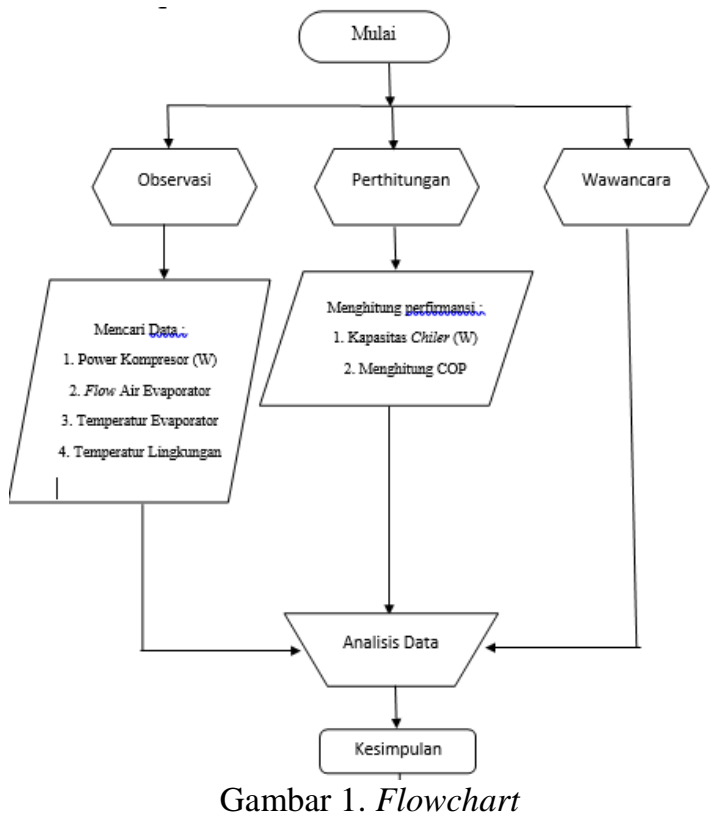

a) Lokasi Penelitian

Tempat melakukan penelitian ini dilakukan di gedung Senaya City, Jakarta Pusat.

b)Metode Pengambilan Data

Penelitian ini adalah penelitian kualitatif. Penelitian ini menggunakan metode analisis deskriptif.

c) Teknik Analisis Data

Analisis dilakukan setelah semua data observasi lengkap. Langkah pertama adalah melakukan perhitungan power kompresor dari bentuk persen angka ke angka desimal. Kemudian menghitung beban pendinginan setiap chiller setiap jam selama 15 hari. Setelah itu melakukan perhitungan COP masing-masing chiller. Langkah terakhir adalah melakukan analisis keseluruhan kinerja chiller meliputi hubungan-hubungan yang berkaitan dengan perhitungan COP.

\section{HASIL DAN PEMBAHASAN Power Kompresor}

Untuk mendapatkan data daya motor kompresor pada masing-masing chiller yang sedang beroperasi, seharusnya bisa dilakukan pengkuran langsung namun Senayan City tidak memiliki fasilitas Power Analyzer. Oleh karena itu, untuk mendapatkan data power kompresor penulis mengambil data resmi audit milik Senayan City. Power motor kompresor chiller 800 TR diukur dengan menggunakan power analyzer, namun tidak demikian halnya untuk power kompresor milik chiller 2000 TR. Power motor kompresor 2000 TR yang menggunakan tegangan $3300 \mathrm{~V}$ tidak dapat diukur oleh karena tidak mempunyai fasilitas untuk mengukur. Untuk mengatasai hal ini, ternyata pihak Senayan City melakukan download data dari database komputer pada panel $20 \mathrm{kV}$ A dan panel $20 \mathrm{kV} \mathrm{B}$.

Untuk saat ini digunakan hasil pengukuran daya motor pada Audit Energi terakhir tahun 2013. Didapat power kompresor chiller 800 TR sebesar $460 \mathrm{~kW}$ dan 2000 TR sebesar $1050 \mathrm{~kW}$. Namun untuk saat ini chiller kapasitas 800 TR sedang dalam masalah pada sisi refrigeran yang kotor sehingga daya kompresor dibatasi hanya $85 \%$ saja. 


\section{Flow Chilled Water}

Untuk mengetahui flow chilled water, Senayan City menggunakan alat ultrasonic flow meter. Keadaan flow chilled water ini selalu berubah-ubah namun tetap pada range. Penulis mengambil sampel sebanyak lima kali perubahan angka flow di setiap chiller. Berikut adalah tabel rata-rata flow chilled water masing-masing chiller :

Tabel 1. Rata-rata flow chilled water

\begin{tabular}{cc}
\hline $\begin{array}{c}\text { Chiller } \\
\text { nomor- }\end{array}$ & $\begin{array}{c}\text { Flow Chilled Water } \\
\text { (gal/menit) }\end{array}$ \\
\hline 1 & 6448 \\
2 & 6362,58 \\
3 & 2423,2 \\
\hline
\end{tabular}

Karena untuk beban pendinginan nanti menggunakan satuan $\mathrm{kkal} / \mathrm{jam}$, maka satuanflow chilled water harus diubah menjadi $\mathrm{m}^{3} / \mathrm{jam}$. Sehingga:

\begin{tabular}{cc}
\multicolumn{2}{c}{$\begin{array}{c}\text { Tabel 2. Nilai flow chilled water dalam } \\
\left(\mathrm{m}^{3} / \mathrm{jam}\right)\end{array}$} \\
\hline $\begin{array}{c}\text { Chiller } \\
\text { nomor- }\end{array}$ & $\begin{array}{c}\text { Flow Chilled Water } \\
\left(\mathrm{m}^{3} / \mathrm{jam}\right)\end{array}$ \\
\hline 1 & 1460 \\
2 & 1463,4 \\
3 & 557,3 \\
\hline
\end{tabular}

\section{Beban Pendinginan Chiller}

Untuk menentukan beban pendinginan chiller digunakan rumus : $\mathbf{Q}=$ Flow $\mathbf{x} \Delta \mathbf{T}$

Dimana flow adalah aliran air dingin pada evaporator dan dT adalah perbedaan temperature air masuk dan keluar evaporator. Beban Pendinginan ini dicari untuk menentukan kapasitas pendinginan. Dimana dari beban pendinginan dengan satuan $\mathrm{kkal} / \mathrm{jam}$ dikonversi ke satuan kapasitas pendinginan TR. Berikut adalah nilai minimum dan maksimum kapasitas pendinginan yang dicapai masing-masing chiller:

Tabel 3. Perbandingan nilai chiller

\begin{tabular}{ccc}
\hline $\begin{array}{c}\text { Chiller } \\
\text { Nomor- }\end{array}$ & $\begin{array}{c}\text { Minimum } \\
\text { (TR) }\end{array}$ & $\begin{array}{c}\text { Maksimum } \\
\text { (TR) }\end{array}$ \\
\hline 1 & 1544,98 & 1990,09 \\
2 & 1548,58 & 1997,37 \\
\hline
\end{tabular}

$3 \quad 479,16 \quad 700,315$

\section{Coefficient of Performance (COP)}

Untuk menentukan performansi chiller harus dihitung nilai COP. Nilai COP harus memenuhi standar minimum SNI. Ketiga chiller yang dimiliki Senayan City termasuk ke dalam jenis chiller > 300 TR dengan menggunakan kompresor sentrifugal. Maka nilai minimum COP yang harus dicapai masing-masing chiller harus 6,05 . Dari hasil perhitungan menurut rumus COP, didapat data sebagai berikut :

\begin{tabular}{ccc} 
Tabel 4. Nilai COP pada chiller \\
$\begin{array}{ccc}\text { Chiller } \\
\text { Nomor- }\end{array}$ & $\begin{array}{c}\text { COP } \\
\text { tertinggi }\end{array}$ & $\begin{array}{c}\text { COP } \\
\text { terendah }\end{array}$ \\
\hline 1 & 7,31 & 5,08 \\
2 & 8,03 & 5,12 \\
3 & 6,27 & 4,22 \\
\hline
\end{tabular}

Dilihat dari tabel COP diatas dapat diketahui bahwa hanya chiller nomor 3 yang memiliko nilai COP yang jauh lebih rendah dari nilai COP chiller nomor 1 dan 2.

\section{KESIMPULAN DAN SARAN Kesimpulan}

1. Nilai $\Delta \mathrm{T}$ Chilled Water tertinggi chiller nomor 1 sebesar $4,17^{\circ} \mathrm{C}$, untuk chiller nomor 2 sebesar $4,27{ }^{\circ} \mathrm{C}$ dan untuk chiller nomor 3 sebesar $3,19^{\circ} \mathrm{C}$. Berarti chiller nomor 3 mempunyai nilai $\Delta \mathrm{T}$ Chilled Water yang paling rendah dibanding chiller 1 dan

2. Kapasitas pendinginan tertinggi yang dapat dicapai chiller nomor 1 sebesar 1990,09 TR , chiller nomor 2 sebesar 1997,37 TR dan chiller nomor 3 sebesar 700,315 TR . Dari nilai tersebut, chiller nomor 3 yang mempunyai nilai kapasitas pendinginan paling rendah dari kapasitas terpasangnya $800 \mathrm{TR}$.

3. Kapasitas pendinginan minimum chiller nomor 1 sebesar 1544,98 TR, chiller nomor 2 se besar 1548,58 TR dan chiller nomor 3 sebesar 479,16 TR. Dari nilainilai tersebut, chiller nomor 3 memiliki nilai minimum kapasitas pendinginan 
paling kecil yaitu hanya sekitar 50\% dari kapasitas terpasang $800 \mathrm{TR}$.

4. Nilai COP tertinggi yang dapat dicapai chiller nomor 1 sebesar 7,31, chiller nomor 2 sebesar 8,03 dan chiller nomor 3 6.27. Ketiga nilai tersebut memenuhi nilai minimum standar COP menurut SNI sebesar 6.05.

5. Nilai COP terendah chiller nomor 1 sebesar 5,08, chiller nomor 2 sebesar 5,12 dan chiller nomor 3 sebesar 4,22. Ketiga nilai minimum COP ketiga chiller ini tidak memenuhi standar minimum COP. Chiller nomor 3 mempunyai angka minimum COP paling rendah dan jauh dibawah stadar minimum sebesar 6.05.

6. Dilihat dari kapasitas pendinginan dan nilai COP, chiller yang kinerja kurang baik adalah chiller nomor 3. Dan chiller yang performanya cukup baik adalah chiller nomor 1 dan 2 .

\section{Saran}

1. Pihak Senayan City harus melakukan strategi mengenai lokasi cooling tower yang sangat jauh untuk meningkatkan nilai $\Delta \mathrm{T}$ Chilled Water agar performansi chiller menjadi lebih baik lagi.

2. Pihak Senayan City, harus melakukan audit energi secara berkala untuk menentukan solusi-solusi yang terjadi pada komponen-komponen sistem pendinginnya.

\section{DAFTAR RUJUKAN}

ASHARE Handbook. 2001. American SocietyHeating Refrigeration and Air Conditioning.

ASHARE Handbook. 2008. System and Equipment.

CP, Arora. 2000. Refrigeration and Air Conditioning Second edition. New Delhi: Tata McGraw-Hill Publishing Company.

Kusbandono, Purwadi. 2001 "Karakteristik Chilled Water",Jurnal Teknologi Industri Vol. V No. 2.

Lexy, J. 2007. Metodologi Penelitian Kualitatif. Bandung: PT Remaja Rosdakarya Offset.

Purwantara.2001 "Pengoperasian Chiller untuk menunjang managemen tata udara
IPLR”, Hasil Penelitian dan Kegiatan PTLR 2001, PTLR-BATAN, Serpong.

SNI 6390 tahun 2011 tentang Konservasi

Energi Sistem Tata Udara Bangunan Gedung.

Stoecker, Wilbert F dan Jerold W. J. 1992. Refrigerasi Dan Pengkondisian Udara, alih bahasa Supratman Hara, Edisi Kelima, Jakarta. Erlangga.

Sugiyono. 2012. Metode Penelitian Kombinasi (Mixed Method). Yogyakarta: Alfabeta

Sukirman, Iwan. 2011. Bahan Ajar, Sistem Tata Udara (HVAC) Digedung Bertingkat.

YORK INTERNATIONAL COOPERATION. 1986. "Air Cooled Packaged Liquid Chiller",

USA. 